\title{
THE INFLUENCE OF ORGANOCLAYS ON THE MORPHOLOGY, PHASE SEPARATION AND THERMAL PROPERTIES OF POLYCARBONATE-BASED POLYURETHANE HYBRID MATERIALS
}

\author{
Jelena Pavličević1 ${ }^{*}$, Milena Špírková ${ }^{2}$, Snežana Sinadinović-Fišer ${ }^{1}$, \\ Jaroslava Budinski-Simendić ${ }^{\text {, Olga Govedarica1, Milovan Janković1 }}$ \\ ${ }^{1}$ Faculty of Technology, University of Novi Sad, R. Serbia \\ ${ }^{2}$ Institute of Macromolecular Chemistry AS CR v.v.i., Prague, Czech Republic \\ jelenapavlicevic@gmail.com
}

Polycarbonate-based polyurethane (PC-PU) nanostructured composites were obtained using a onestep technique, by the addition of $1 \mathrm{wt} . \%$ organically modified clays (either bentonite or montmorillonite). Only aliphatic components (polycarbonate diol, hexamethylene-diisocyanate and 1,4-butane diol) were used as reactants. The hard segment content of the obtained polyurethanes was $30 \mathrm{wt} . \%$. Scanning electron microscopy (SEM) and Fourier transform infrared spectroscopy (FT-IR) were performed to investigate the morphology and hydrogen bonding formation in prepared elastomers. The influence of nanofiller addition on thermal properties of PC-PUs was studied using differential scanning calorimetry (DSC). The degree of phase separation of polyurethane nanocomposites was not influenced by the dispersion of silicate layers in the elastomeric matrix. It was determined that bentonite and montmorillonite affect the melting transition of hard segments and the recrystallization process, which is very important for the processing and recycling of the prepared polyurethane hybrid materials.

Keywords: polycarbonate-based polyurethane; bentonite; montmorillonite; phase separation; thermal properties

\section{ВЛИЈАНИЕ НА ОРГАНСКИТЕ ГЛИНИ ВРЗ МОРФОЛОГИЈАТА, РАЗДВОЈУВАҢЕТО НА ФАЗИТЕ И ТЕРМИЧКИТЕ ОСОБИНИ НА ПОЛИУРЕТАНСКИ ХИБРИДНИ МАТЕРИЈАЛИ БАЗИРАНИ НА ПОЛИКАРБОНАТИ}

Нанокомпозитни полиуретани базирни на поликарбонати (PC-PU - од анг. PolycarbonateBased Polyurethane) беа добиени со техника во еден чекор со додавање на $1 \%$ органски модифицирани глини (бентонити или монтморилонити). Како реактанти беа користени само алифатични компоненти (поликарбонатен диол, хексаметилендиизоцијанат и 1,4-бутандиол). Содржината на „тврдиот сегмент“ на добиените полиуретани изнесуваше 30 \%. За испитување на морфологијата и водородното сврзување во еластомерите беа користени методите SEM и FT-IR. Влијанието на додавањето на нанополнителите на термичките особини на PC-PU беше испитувано со методот DSC (од анг. Differential Scanning Calorimetry). Степенот на фазното разделување на полиуретанските нанокомпозити не зависи од дисперзијата на силикатните слоеви во еластомерскиот матрикс. Најдено е дека бентонитот и монтморилонитот влијаат на точката на фазниот премин на топење на „тврдиот сегмент“ и на процесот на кристализација, кој е многу важен при обработка и рециклирање на готовите полиуретански хибридни материјали.

Клучни зборови: полиуретани базирани на поликарбонати; бентонит; монтморилонит; фазен премин; термички особини 


\section{INTRODUCTION}

Polyurethanes prepared from macrodiol, diisocyanate and a short diol (as a chain extender) are mostly linear multiblock copolymers, belonging to the typical thermoplastic elastomers with a segmental structure. Unlike crosslinked elastomeric networks, thermoplastic polyurethanes demonstrate elastomeric properties due to physical crosslinks formed as a result of microphase separation between hard and soft segments. These materials are characterized by rubber-like behavior, and, unlike conventional rubbers, they can be processed and recycled like thermoplastics. Typically, soft segments provide elasticity and flexibility at room temperature and they are above the glass transition temperature of the material, while hard segments are below their glassy or melt transition temperature and offer the necessary physical crosslink sites [1], imparting elastomeric behavior to the material. Since the hard domains occupy a significant volume and are stiffer than the soft domains, they also behave as an effective nano-scale filler [2]. The soft segments are formed from the macrodiol component, while the hard segments are the reaction product of diisocyanate and chain extender building blocks. The major hydrogen bonds are formed between urethane groups (hardhard segment interaction) and between urethane and carbonate groups (hard-soft segment mixing) [3]. The incompatibility of the hard and soft phase leads to microphase segregated structure of polyurethane elastomers, and affects their properties [4].

Due to their specific microphase-separated structure, segmented polycarbonate-based polyurethanes (PC-PUs) have attracted a lot of attention in different industrial and engineering applications. These thermoplastic elastomers can be used as building materials, for industrial parts, and for medical equipment (due to their good biostability and biocompatibility) [5-7]. More expensive polycarbonate-based polyurethanes possess superior mechanical and thermal properties, along with excellent heat, oxidative, hydrolysis and UVlight resistance in regard to traditional polyetheror polyester- based polyurethanes [8-11]. The backbone constitution and molecular weight of polycarbonate diols affect the morphological, mechanical and thermal properties of polyurethanes $[12,13]$. The most commonly used aliphatic polycarbonate diols are based on poly(hexamethylene carbonate) diol $[14,15]$ or on their copolymers containing 2-10 alkane units [7, 16, 17].

Polymer nanocomposites are inorganic/organic hybrid systems with the matrix reinforced by nanosized particles [18]. Organoclay layered silicates are the materials of choice for nanocomposite design because they exhibit very rich intercalation chemistry. They are natural clay minerals modified by organic cations and can be treated as a filler added to improve the strength and stiffness of a polymer matrix. The improvement in the physical properties of nanocomposites greatly depends on the dispersion of clay platelets into the polymer, which is connected to the compatibility between the two components and the processing technique [19]. In order to improve their dispersion in a polymer matrix, clay platelets can be chemically modified [20]. The replacement of inorganic exchange cations by organic onium ions on the gallery surface of smectite clays serves to match the polarity of the clay surface with the polarity of the polymer and to expand the clay galleries [21].

Polyurethane-organoclay hybrids have been the subject of intensive research interest as elastomeric materials with significantly improved properties compared to the parent materials [2225]. The presence of nanoparticles with a layered structure increases the reaction between the hard segments and organoclays, causing additional hydrogen bonding formation and an enhancement of the thermal and mechanical properties of polyurethane nanostructured composites [7, 26]. Many researchers have investigated the microdomain structure of segmented polyurethanes and isocyanate conversion using Fourier transform infrared spectroscopy (FT-IR) [27, 28]. Differential scanning analysis (DSC) has often been performed to obtain information on the structural and phase transitions of polymers, such as glass transition, melting, and crystallization processes $[29,30]$. 
In this paper, the influence of the addition of organoclays, namely bentonite or montmorillonite, on the nanometre-scale physical structure of polyurethanes, hydrogen bonding formation, morphology and the degree of phase separation of hybrid materials was studied. Polyurethane/organoclay nanocomposites were also investigated with respect to their thermal properties, and the effect of bentonite or montmorillonite addition on the structural melting transition of hard segments and the recrystallization process of the prepared materials is discussed.

\section{EXPERIMENTAL}

\subsection{Materials}

Aliphatic polycarbonate diol PC T4671 with a molecular weight of 1000 (OH value: 109.9 mg KOH/g) was kindly provided by Asahi Kasei Chemical Corporation. The macrodiol nomenclature is the following: the first two numbers are related to methylene units in the copolymer ( $\mathrm{C} 4$ and C6 units), the third is the molar ratio of the butane units, and the last number indicates the thousand digits of the molecular weight of the polycarbonate diol. The chain extender, 1,4-butane diol (1,4BD), hexamethylene-diisocyanate (HDI), and a catalyst, dibutyltin dilaurate (DBTDL), were all obtained from Fluka. As fillers, nanoparticles of organically modified bentonite (Bentonite for organic systems, BO, Fluka) and organically modified montmorillonite (Cloisite ${ }^{\circledR} 15 \mathrm{~A}$, Southern Clay Products, Inc.) were used (Figure 1).

a)
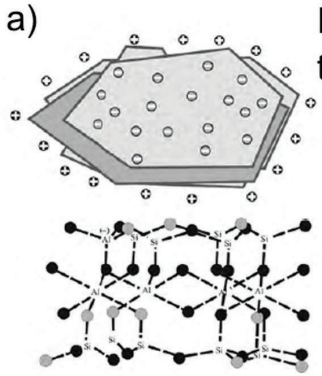

$\bullet \mathrm{O} ; \bullet \mathrm{OH} ; \bullet \mathrm{Si}, \mathrm{Al} ; \bullet A \mathrm{Al}, \mathrm{Fe}, \mathrm{Mg}$

Fig. 1. The structure of organoclays with a layered structure used as nanofillers:

a) bentonite and b) montmorillonite

\subsection{Sample preparation}

During the one-step synthesis of unfilled and filled PC-PUs, the ratio of isocyanate and hydroxyl groups $r$ was kept constant (1.05), and the number of $\mathrm{OH}$ groups from the chain extender and macrodiol was equal $(R=1)$. The synthesis started with the addition of $1 \mathrm{wt} . \%$ organically modified clay (bentonite or montmorillonite) to the macrodiol component; the mixture was then stirred for $24 \mathrm{~h}$ to ensure good dispersion of the nanofillers. Then, 1,4-BD and DBTDL solutions in Marcol oil (0.05 wt.\%) were poured in. At the end, hexamethylene-diisocyanate was added to the mixture and stirred for 10 minutes. The prepared multicomponent system was degassed for $15 \mathrm{~min}$, in order to remove potential bubbles, and finally spread in Teflon molds to form an elastomeric sheet with a thickness of about $2 \mathrm{~mm}$. The structure of the obtained polyurethane elastomeric material is given in Figure 2.



Fig. 2. Schematic illustration of the structure of polycarbonate-based polyurethane nanocomposite

\subsection{Fourier transform infrared spectroscopy (FT-IR)}

The chemical structure of polycarbonatebased polyurethane nanocomposites was performed by Fourier transform infrared spectroscopy on a Thermo Nicolet Nexus 670 FT-IR-ATR spectrometer, with a resolution of $2 \mathrm{~cm}^{-1}$. A single beam spectrum was obtained after averaging 40 scans between 4000 and $500 \mathrm{~cm}^{-1}$.

\subsection{Scanning electron microscopy (SEM)}

The study of nanofiller morphology and phase structure of the prepared hybrid materials 
was carried out using a JEOL JSM-6460 scanning electron microscope at magnifications from $10^{3}$ to $2 \times 10^{6}$ at $25 \mathrm{kV}$. Before measurements, the sample surfaces were coated with gold by applying a sputter coating procedure, using a BAL-TEC SCD 005 instrument, under vacuum of $10^{-6}$ Torr for $90 \mathrm{~s}$ and at $30 \mathrm{~mA}$, in order to avoid charging under the electron beam.

\subsection{Differential scanning calorimetry (DSC)}

The investigation of thermal properties of segmented thermoplastic unfilled and filled polycarbonate-based polyurethanes prepared by the one-step technique was done using a DSC Q20 differential scanning calorimeter (TA Instruments). The instrument was calibrated using an indium standard. The samples mass was about 3 mg. All measurements were performed under a nitrogen atmosphere, at a purge gas flow rate of $50 \mathrm{~cm}^{3} / \mathrm{min}$. In order to study the influence of nanoclays on the hard segment melting region and recrystallization, two DSC runs were performed with heating and cooling rates of $5{ }^{\circ} \mathrm{C} / \mathrm{min}$, in the temperature range from 30 to $190^{\circ} \mathrm{C}$. The melting temperatures of the hard domains $\left(T_{m}\right)$ were detected at the endothermic peak maxima. The temperature of hard segment recrystallization $\left(T_{\text {rec }}\right)$ and heat of recrystallization $\left(\Delta H_{\text {rec }}\right)$ were analyzed from the cooling DSC curves.

\section{RESULTS AND DISCUSSION}

\subsection{Morphology and structure of unfilled and filled PC-Pus}

Prepared unfilled and filled polycarbonatebased polyurethane elastomers possess a separated phase structure, with hard and soft segments. The good mechanical properties of these thermoplastic materials are derived from the hard segments which are made from 1,4-butane diol and hexamethylene-diisocyanate, while their low glass transition temperature is ascribed to aliphatic polycarbonate diol.

SEM micrographs of the organically modified clays as well as the prepared PC-PUs are presented in Figure 3.


Fig 3. SEM micrographs of: a) organically modified bentonite; b) organically modified montmorillonite;

c) PC-PU nanocomposite with $1 \mathrm{wt} . \%$ bentonite and d) PC-PU nanocomposite with $1 \mathrm{wt} . \%$ montmorillonite 


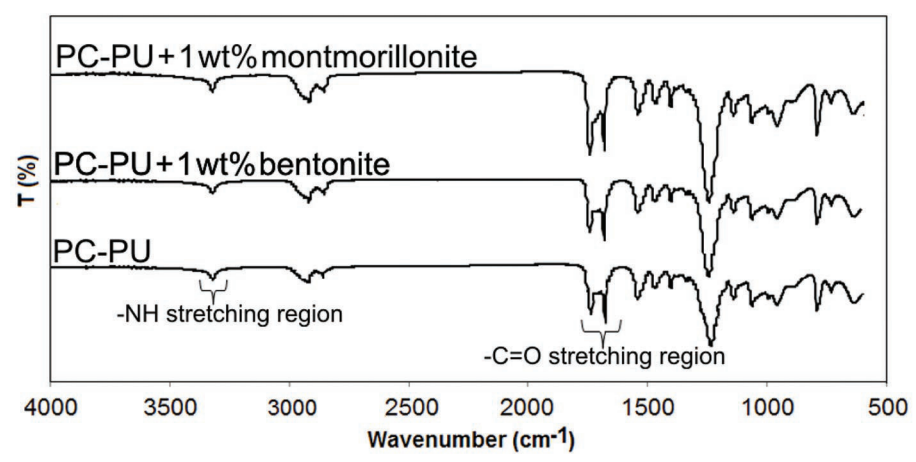

Fig. 4. FT-IR spectra of the unfilled and filled segmented polycarbonate-based polyurethane elastomers

Figs. 3a and 3b display SEM micrographs of bentonite and montmorillonite, respectively, where the thickness of the layers and the distance between layers were confirmed to be on nanometer scale. The SEM micrographs of PC-PU elastomers reinforced with $1 \mathrm{wt} . \%$ bentonite or $1 \mathrm{wt} . \%$ montmorillonite (Figures 3c and 3d, respectively) show the phase separated structure of the obtained nanocomposites. The soft domains possess a smoother surface morphology, while the hard segments (acting like physical crosslinks) are characterized by a hillier and coarser surface. On the basis of the morphological study of the prepared hybrid materials, it can be noted that the achieved dispersion of bentonite or montmorillonite nanoparticles in the polyurethane matrix was relatively uniform and homogenous (brighter spots were detected on the surface of the hard segments). The average size of the dispersed bentonite and montmorillonite particles, determined from the SEM micrographs of PC-PU hybrids, was around 25 and $35 \mathrm{~nm}$, respectively.

The FT-IR spectra of the unfilled and filled PC-PU elastomeric materials are displayed in Figure 4.

There were no detected bands associated with non-bonded $-\mathrm{NH}$ groups in the infrared range from 3450 to $3500 \mathrm{~cm}^{-1}$. It can be concluded that full isocyanate group conversion was achieved since no isocyanate band at ca. 2270 $\mathrm{cm}^{-1}$ was registered. A description of bands found in the IR spectra of the prepared polyurethane nanostructured materials is given in Table 1 .
Table 1

The assignation of characteristic bands in the IR spectra of the obtained unfilled and filled polyurethane nanostructured materials

\begin{tabular}{|c|c|}
\hline $\begin{array}{l}\text { Position of IR bands; } \\
\text { wavenumber }\left(\mathrm{cm}^{-1}\right)\end{array}$ & Band assignation \\
\hline $3200-3450$ & -NH streching region \\
\hline 2932 & $\begin{array}{l}-\mathrm{CH}_{2} \text { anti-symmetry stretch } \\
\text { vibration band in soft } \\
\text { segment }\end{array}$ \\
\hline 2852 & $\begin{array}{l}-\mathrm{CH}_{2} \text { symmetry stretch } \\
\text { vibration band in soft } \\
\text { segment }\end{array}$ \\
\hline $1600-1800$ & $-\mathrm{C}=\mathrm{O}$ stretching regions \\
\hline 1533 & $\begin{array}{l}\text { joint frequency of the } \\
\text { symmetry vibration of } \mathrm{N}-\mathrm{H} \\
\text { bond and } \\
\text { stretch vibration of the amidic } \\
\mathrm{C}-\mathrm{N} \text { bond }\end{array}$ \\
\hline 1460 & $\begin{array}{l}\text { the symmetrical bending } \\
\text { vibration of }-\mathrm{CH}_{2}\end{array}$ \\
\hline 1251 & $\begin{array}{l}\text { the anti-symmetrical vibration } \\
\text { of the } \mathrm{O}-\mathrm{C}=\mathrm{O} \text { in the soft } \\
\text { segment }\end{array}$ \\
\hline 1087 & $\begin{array}{l}\text { the stretch vibration of the } \\
\mathrm{C}-\mathrm{O}-\mathrm{C} \text { in urethane units }\end{array}$ \\
\hline 927 & $\begin{array}{l}\text { the symmetry stretch } \\
\text { vibration of the } \mathrm{C}-\mathrm{O}-\mathrm{C} \text { in } \\
\text { carbonate }\end{array}$ \\
\hline
\end{tabular}

It is well-known that $-\mathrm{NH}$ and $-\mathrm{C}=\mathrm{O}$ bands in FT-IR are two typical bands used to analyze $\mathrm{H}$-bonding in polyurethanes and their frequencies are usually used to study H-bond 
strength [28]. In order to obtain information about the effect of organoclay addition on the phase separation and hydrogen bonding formation, the deconvolution method was applied on the $-\mathrm{NH}$ and $-\mathrm{C}=\mathrm{O}$ stretching absorbance regions (from 3200 to $3450 \mathrm{~cm}^{-1}$ and from 1600 to $1800 \mathrm{~cm}^{-1}$, respectively). Deconvolution was done using Gaussian curves to give the best fits [31]. As an example of applied deconvolution, the deconvoluted areas of the FT-IR spectrum of polyurethane with bentonite are presented in Figure 5.


Fig. 5. Deconvolution of

a) -NH stretching absorbance region of PC-PU with 1 wt.\% bentonite and $\mathrm{b}$ ) $-\mathrm{C}=\mathrm{O}$ stretching absorbance region of PC-PU with 1 wt.\% bentonite
In Figure 5a, sharp band 2 at $3319 \mathrm{~cm}^{-1}$ was assigned to the vibration of $\mathrm{H}$-bonded $-\mathrm{NH}$ groups. The additional hydrogen bonding, formed due to the interaction between the hard segments of polyurethane and reinforced organoclay fillers, caused an increase in the band 2 area. Streching vibrations registered at 3277 and $3372 \mathrm{~cm}^{-1}$ were connected to the interaction of $-\mathrm{NH}$ groups with strong carbonyl carbonate groups (bands 1 and 3, respectively). The best choice to investigate the influence of intercalated silicate layers on the degree of phase separation (DPS) in the structure of polyurethanes is to calculate it from the extent of hydrogen bonding in the hard domains [32]. For this reason, deconvolution of the carbonyl $(\mathrm{C}=\mathrm{O})$ absorbance region is performed (Fig $5 \mathrm{~b}$ ). Non-H-bonded (free) carbonyl $(\mathrm{C}=\mathrm{O})$ groups of the aliphatic carbonate were found at 1741 $\mathrm{cm}^{-1}$ (band A). The band detected at $1718 \mathrm{~cm}^{-1}$ was assigned to carbonyl H-bonded groups in disordered phases (band B). The band at 1682 $\mathrm{cm}^{-1}$ was assigned to $\mathrm{H}$-bonded $\mathrm{C}=\mathrm{O}$ groups in ordered hard domains (band C). Band D, which appeared as a shoulder at $1657 \mathrm{~cm}^{-1}$, was assigned to the vibrations of $\mathrm{H}$-bonded (carbonate) carbonyl groups in the polycarbonate diol (soft segment). The calculated band areas found in the carbonyl stretching region are given in Table 2. The interactions between the hard segments (formed from HMDI/1,4-BD building blocks) and organoclay nanoparticles are significantly stronger compared to the interactions on the border between hard and soft segments, causing phase separation of the domains [14]. The calculated surface area of band B (assigned to hard segments) was about $30 \%$ for all samples, which is in accordance with the theoretically calculated hard segment content (based on the masses of starting components).

Hydrogen bonding formation can be studied on the basis of the position and area of bands (A, B, C and D) determined after the deconvolution of the carbonyl region. Three bands at 1718, 1682 and $1657 \mathrm{~cm}^{-1}$ were attributed to $\mathrm{H}$-bonded $-\mathrm{C}=\mathrm{O}$, and one at 
$1741 \mathrm{~cm}^{-1}$ was assigned to free $-\mathrm{C}=\mathrm{O}[7]$. The degree of phase separation (DPS) of segmented themoplastic PC-PUs can be calculated using Equation 1 [33].

$$
\mathrm{DPS}=\frac{\mathrm{A}_{\text {bonded }, \text { tot }}}{\mathrm{A}_{\text {tot }}}=\frac{\mathrm{A}_{1718}+\mathrm{A}_{1682}+\mathrm{A}_{1657}}{\mathrm{~A}_{1718}+\mathrm{A}_{1682}+\mathrm{A}_{1657}+\mathrm{A}_{1741}}
$$

The obtained values of DPS are given in Table 2.

The obtained phase separation degree was not dependent on bentonite or montmorillonite addition (the DPS values for unfilled and filled PC-PU samples were in the range from 73 to $75 \%$ ). These results could be explained by the achieved uniform dispersion of $1 \mathrm{wt} . \%$ layered silicates in the polyurethane matrix.

On the basis of the FT-IR results, it can be concluded that organoclays cause additional hydrogen bonding due to the interaction with hard domains, but do not change the phase separation behavior since proper nanoparticle dispersion was achieved, which was also observed in the SEM images of the obtained hybrid materials.

\subsection{The influence of organoclay addition on the thermal properties of PC-PU elastomers}

Thermoplastic polycarbonate-based polyurethanes usually exhibit several phase transitions due to their microstructure formed of hard and soft segments (Figure 3 ) and the strong intermolecular interaction of hydrogen bonding between the hard-hard segments of urethane linkages (Figure 5). The effect of organoclay addition on the glass transition temperature $T_{g}$ of polyurethanes has already been studied, and no influence of bentonite or montmorillonite was found on the restriction of soft segments (the $T_{g}$ value was determined at $-32{ }^{\circ} \mathrm{C}$ for unfilled and filled samples) [13]. This work aimed to investigate the influence of bentonite or montmorillonite addition on the melting region of hard segments and the recrystallization region of the prepared hybrid materials. To this purpose, the first and second DSC runs of the unfilled and filled polyurethane nanostructured elastomers are shown in Figure 6.

The first heating curves of polyurethane elastomers and their nanocomposites based on polycarbonate diol type 4671 were characterized by one endothermic change registered at around $50{ }^{\circ} \mathrm{C}$, which can be connected to the existence of a diffused interfacial phase be-

Ta b l e 2

The areas of the bands in the carbonyl stretching region and the phase separation degree of the obtained polycarbonate-based polyurethanes

\begin{tabular}{lccccc}
\hline \hline Sample & $\begin{array}{c}\text { Band A area } \\
(\%)\end{array}$ & $\begin{array}{c}\text { Band B area } \\
(\%)\end{array}$ & $\begin{array}{c}\text { Band C area, } \\
(\%)\end{array}$ & $\begin{array}{c}\text { Band D area, } \\
(\%)\end{array}$ & $\begin{array}{c}\text { Phase separation degree } \\
(\%)\end{array}$ \\
\hline PC-PU & 1.8 & 31.9 & 39.9 & 26.4 & 73.5 \\
\hline $\begin{array}{l}\text { PC-PU + } \\
1 \text { wt.\% bentonite }\end{array}$ & 2.0 & 29.8 & 41.2 & 27.0 & 73.6 \\
\hline $\begin{array}{l}\text { PC-PU + } \\
\begin{array}{l}1 \text { wt.\% } \\
\text { montmorillonite }\end{array}\end{array}$ & 1.6 & 30.8 & 40.9 & 26.7 & 75.2 \\
\hline \hline
\end{tabular}



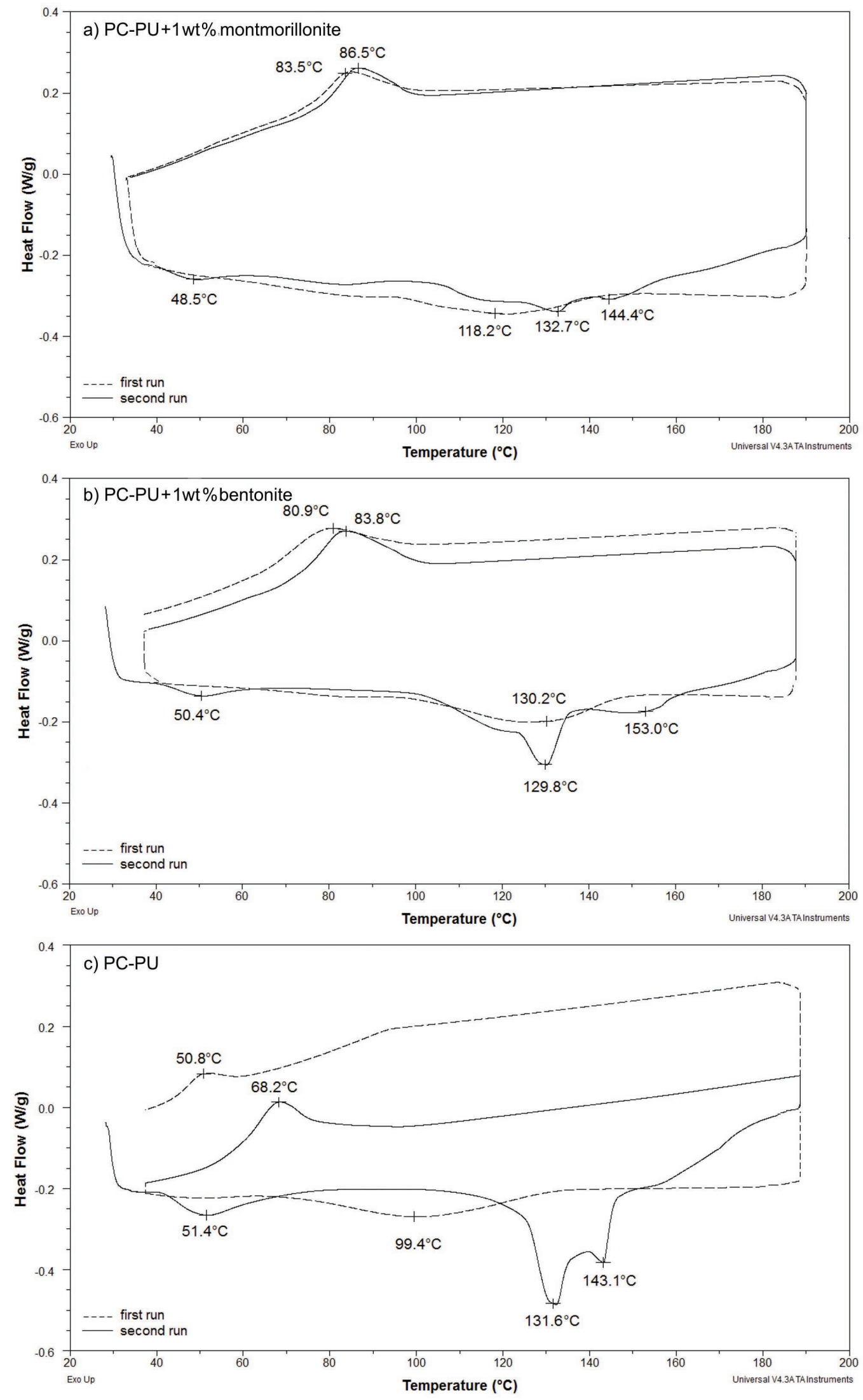

Fig. 6. Thermal curves (heating and cooling) of heat flow $v s$. temperature for: a) PC-PU with 1 wt. $\%$ montmorillonite,

b) PC-PU with 1 wt.\% bentonite and c) the unfilled PC-PU elastomer 
tween the soft and hard segments due to the order-disorder relaxation of the PU chains at the interface $[30,34]$ or the melting of non-crystalline hard segment domains [16]. The addition of organoclay had no influence on that event, shifting only slightly its temperature minimum to lower values (from $51.4{ }^{\circ} \mathrm{C}$ to $50.4{ }^{\circ} \mathrm{C}$ with bentonite addition, and from $51.4{ }^{\circ} \mathrm{C}$ to $48.5^{\circ} \mathrm{C}$ with montmorillonite addition). This change was not detected in the second DSC curve, indicating the existence of relaxation of the chain segments in the diffused interphase between the hard and soft segments [30].

In the first heating run, two endotherms with minima $T_{m}$ above $100{ }^{\circ} \mathrm{C}$ connected with the melting of hard segments (initiation of physical crosslink disruption) can be observed. In the second heating scan, only one broad melting endotherm was registered. The temperature of hard segment melting is influenced by nanoparticle dispersion. In the case of polyurethane filled with bentonite nanoparticles, the additional heating caused ordering of the hard domains and, for this reason, the initiation of physical crosslink disruption appeared at higher temperatures $\left(130.2^{\circ} \mathrm{C}\right)$. During the second heating run, the melting of the hard segments of the PC-PU sample without organoclay appeared at a significantly lower temperature (by about $30^{\circ} \mathrm{C}$, Figure $6 \mathrm{c}$ ) compared to the melting temperature observed in the first heating curve. The enthalpy of hard segment melting region of the studied polyurethanes $\left(\Delta H_{m}\right)$ decreased with bentonite or montmorillonite addition, indicating the good incorporation of organoclays into polyurethane matrix (from $15.8 \mathrm{~J} / \mathrm{g}$ for unfilled PC-PU to $9.8 \mathrm{~J} / \mathrm{g}$ for the elastomer with bentonite and $6.4 \mathrm{~J} / \mathrm{g}$ for the sample filled with montmorillonite), which is very important data for the processing of prepared polyurethane hybrid materials.

The first cooling DSC curve of the unreinforced elastomer (Figure 6c) shows retarded solidification above $68^{\circ} \mathrm{C}$ assigned to the crystallization of hard segments. With the addition of organically modified bentonite or montmorillonite, the recrystallization temperature $\left(T_{r e c}\right)$ of the nanocomposites increased from $68^{\circ} \mathrm{C}$ to $84{ }^{\circ} \mathrm{C}$ and $87{ }^{\circ} \mathrm{C}$, respectively, indicating the achievement of a higher crystallization rate due to presence of nanoclay with a layered structure, which acted as a nucleating agent [19]. Crystallization was improved with bentonite or montmorillonite addition $\left(\Delta \mathrm{H}_{\text {rec }}\right.$ increased from $5.2 \mathrm{~J} / \mathrm{g}$ for the unfilled sample to $6.9 \mathrm{~J} / \mathrm{g}$ and $6.5 \mathrm{~J} / \mathrm{g}$, respectively). The significant difference between $T_{m}$ and $T_{r e c}$ values might be ascribed to a slow process of hard domain recrystallization [31]. In Figures $6 \mathrm{a}$ and 6b, it can be seen that the influence of additional heating on the recrystallization temperature was less pronounced for the samples reinforced with 1 wt.\% organoclays (the $T_{\text {rec }}$ value was decreased by only about $3{ }^{\circ} \mathrm{C}$ in the second cooling curve of the polyurethanes with montmorillonite or bentonite nanofillers), indicating a stabilization effect of organoclays on the crystallization process of PC-PU nanocomposites. On the other hand, the second cooling of the unreinforced PC-PU elastomer caused a significant decrease in the recrystallization temperature from $68{ }^{\circ} \mathrm{C}$ to $59^{\circ} \mathrm{C}$ (Figure $6 \mathrm{c}$ ). These results are very useful for the recycling process of prepared thermoplastic polyurethanes.

Acknowledgments. The authors from Novi Sad would like to acknowledge to the Ministry of Education, Science and Technological Development of the Republic of Serbia for providing financial support (Project No. III45022). The author from Prague expresses gratitude to the Grant Agency of the Czech Republic (Czech Science Foundation, project No. P108/10/0195). The authors are also thankful to DAAD and INFU, FR Germany, for the donation of instruments.

\section{REFERENCES}

[1] S. S. Liow, V. T. Lipik, L. K. Widjaja, S. S. Venkatraman, M. J. M. Abadie, Enhancing mechanical properties of thermoplastic polyurethane elastomers with 1,3-trimethylene carbonate, epsilon-caprolactone and 1-lactide copolymers via soft segment crystallization, Express Polym. Lett., 5, 897-910 (2011). 
[2] Z. S. Petrović, J. Ferguson, Polyurethane elastomers, Prog. Polym. Sci., 16, 695-836 (1991).

[3] M. Špírková, R. Poręba, J. Pavličević, L. Kobera, J. Baldrian, M. Pekárek, Aliphatic polycarbonatebased polyurethane elastomers and nanocomposites. I. The influence of hard-segment content and macrodiol-constitution on bottom-up self-assembly, J. Appl. Polym. Sci., 126, 1016-1030 (2012).

[4] C. Prisacariu, Polyurethane Elastomers. From Morphology to Mechanical Aspects, Springer Verlag, Wien, 2011.

[5] M. Špírková, A. Strachota, M. Urbanová, J. Baldrian, J. Brus, M. Šlouf, A. Kuta, Z. Hrdlička, Structural and surface properties of novel polyurethane films, Mater. Manuf. Process., 24, 1185 1189 (2009).

[6] I. Khan, N. Smith, E. Jones, D.S. Finch, R. E. Cameron, Analysis and evaluation of a biomedical polycarbonate urethane tested in an in vitro study and an ovine arthroplasty model. Part I: Materials selection and evaluation, Biomaterials, 26, 621631 (2005).

[7] M. Špírková, J. Pavličević, A. Strachota, R. Poreba, O. Bera, L. Kaprálková, J. Baldrian, M. Šlouf, N. Lazić, J. Budinski-Simendić, Novel polycarbonate-based polyurethane elastomers: Composition-property relationship, Eur. Polym. J., 47, 959-972 (2011).

[8] A. Kultys, R. Rogułska, S. Pikus, K. Skrzypiec, The synthesis and characterization of new thermoplastic poly(carbonate-urethane) elastomers derived from HDI and aliphatic-aromatic chain extenders, Eur. Polym. J., 45, 2629-2643 (2009).

[9] E. M. Christenson, J. M. Anderson, A. Hiltner, Antioxidant inhibition of poly(carbonate urethane) in vivo biodegradation, J. Biomed. Mater. Res. A, 76, 480-490 (2006).

[10] A. Eceiza, M. D. Martin, K. de la Caba, G. Kortaberria, N. Gabilondo, M. A. Corcuera, I. Mondragon, Thermoplastic polyurethane elastomers based on polycarbonate diols with different soft segment molecular weight and chemical structure: Mechanical and thermal properties, Polym. Eng. Sci., 48, 297-306 (2008).

[11] H. Tanaka, M. Kunimura, Mechanical properties of thermoplastic polyurethanes containing aliphatic polycarbonate soft segments with different chemical structures, Polym. Eng. Sci., 42, 1333 1349 (2002).

[12] Z. W. Ma, Y. Hong, D. M. Nelson, J. E. Pichamuthu, C. E. Leeson, W. R. Wagner, Biodegrad- able polyurethane ureas with variable polyester or polycarbonate soft segments: Effects of crystallinity, molecular weight, and composition on mechanical properties, Biomacromolecules, 12, 3265-3274 (2011).

[13] J. Pavličević, M. Špirková, A. Strachota, K. Mészáros Szécsényi, N. Lazić, J. BudinskiSimendić, The influence of montmorillonite and bentonite addition on thermal properties of polyurethanes based on aliphatic polycarbonate diols, Thermochim. Acta, 509, 73-80 (2010).

[14] K. Kojio, M. Furukawa, S. Motokucho, S. Shimada, M. Sakai, Structure-mechanical property relationships for polycarbonate urethane elastomers with novel soft segments, Macromolecules, 42, 8322-8327 (2009).

[15] A. Kultys, M. Rogułska, New thermoplastic poly(carbonate-urethane) elastomers, Pol. J. Chem. Technol, 13, 23-30 (2011).

[16] K. Kojio, Y. Nonaka, T. Masubuchi, M. Furukawa, Effect of the composition ratio of copolymerized poly(carbonate) glycol on the microphase-separated structures and mechanical properties of polyurethane elastomers, J. Polym. Sci. Part B: Polym. Phys., 42, 4448-4458 (2004).

[17] R. Hernandez, J. Weksler, A. Padsalgikar, T. Choi, E. Angelo, J. S. Lin, L. C. Xu, C. A. Siedlecki, J. Runt, A comparison of phase organization of model segmented polyurethanes with different intersegment compatibilities, Macromolecules, 41, 9767-9776 (2008).

[18] M. Stankowski, A. Kropidlowska, M. Gazda, J. T. Haponiuk, Properties of polyamide 6 and thermoplastic polyurethane blend containing modified montmorillonites, J. Therm. Anal. Calorim., 94, 817-823 (2008).

[19] H. F. Naguib, M. S. Abdel Aziz, G. R. Saad, Synthesis, morphology and thermal properties of polyurethanes nanocomposites based on poly(3hydroxybutyrate) and organoclay, J. Ind. Eng. Chem., in press (2012), http://dx.doi.org/10.1016/j. jiec.2012.06.023

[20] A. Usuki, M. Kato, A. Okada, T. Kurauchi, Synthesis of polypropylene-clay hybrid, J. Appl. Polym. Sci., 63, 137-138 (1997).

[21] M. Song, H. S. Xia, K. J. Yao, D. J. Hourston, A study on phase morphology and surface properties of polyurethane/organoclay nanocomposite, Eur. Polym. J., 41, 259-266 (2005).

[22] A. Leszczynska, J. Njuguna, K. Pielichowski, J. R. Banerjee, Polymer/montmorillonite nanocompos- 
ites with improved thermal properties: Part I. Factors influencing thermal stability and mechanisms of thermal stability improvement, Thermochim. Acta., 453, 75-96 (2007).

[23] A. K. Barick, D. K. Tripathy, Effect of organically modified layered silicate nanoclay on the dynamic viscoelastic properties of thermoplastic polyurethane nanocomposites, Appl. Clay Sci., 52, 312 321 (2011).

[24] N. Sarier, E. Onder, Organic modification of montmorillonite with low molecular weight polyethylene glycols and its use in polyurethane nanocomposite foams, Thermochim. Acta 510, 113-121 (2010).

[25] F. Chavarria, D. R. Paul, Morphology and properties of thermoplastic polyurethane nanocomposites: Effect of organoclay structure, Polymer, 47, 7760-7773 (2006).

[26] J. Pavličević, S. Sinadinović-Fišer, J. BudinskiSimendić, O. Borota, M. Janković, M. Špírková, $\check{Z}$. Knez, The phase structure of novel polycarbonate-based polyurethane-organoclay nanocomposites, Advanced Material Research, 560-561, 771-775 (2012).

[27] L. R. Larraz, B. F. d'Arlas, A. Tercjak, A. Ribes, I. Mondragon, A. Eceiza, Synthesis and microstructure-mechanical property relationships of segmented polyurethanes based on a PCL-PTHFPCL block copolymer as soft segment, Eur. Polym. J., 45, 2096-2109 (2009).
[28] C. Zhang, Z. Ren, Z. Yin, H. Qian, D. Ma, Amide II and amide III bands in polyurethane model soft and hard segments, Polym. Bull., 60, 97-101 (2008).

[29] B. Finnigan, D. Mattin, P. Halley, R. Truss, K. Campbell, Morphology and properties of thermoplastic polyurethane nanocomposites incorporating hydrophilic layered silicates, Polymer, 45, 2249-2260 (2004).

[30] J. Jin, M. Song, K. J. Yao, A MTDSC analysis of phase transition in polyurethane-organoclay nanocomposites, Thermochim. Acta, 447, 202-208 (2006).

[31] J. Pavličević, M. Špírková, M. Jovičić, O. Bera, R. Poreba, J. Budinski-Simendić, The structure and thermal properties of novel polyurethane/organoclay nanocomposites obtained by pre-polymerization, Composites, Part B, in press (2012).

[32] T. K. Chen, Y. I. Tien, K. H. Wei, Synthesis and characterization of novel segmented polyurethane/ clay nanocomposites, Polymer, 41, 1345-1353 (2000).

[33] R. W. Seymour, G. M. Ester, S. L. Cooper, Infrared studies of segmented polyurethane elastomers. I. Hydrogen bonding, Macromolecules, 3, 579-583 (1970).

[34] R. W. Seymour, S. L. Cooper, Thermal analysis of polyurethane block polymers, Macromolecules, 6 , 48-53 (1973). 
